\title{
Performance as Transformation: The Laughing Songs of Death in Venice in Literature, Film, and Opera
}

\author{
Janina Müller
}

In a scene towards the end of Thomas Mann's novella Death in Venice (1912), a musical performance leads to an outburst of laughter. Shortly after the protagonist Gustav von Aschenbach becomes aware that cholera is spreading in the city of Venice, a band of Neapolitan street musicians entertains the unsuspecting guests of the Grand Hôtel des Bains on the Lido. Both Aschenbach and his beloved Tadzio are present in what seems to be a precarious situation: the boy constantly turns his gaze toward the older man, who is trying hard to keep his affection from being noticed by Tadzio's family. Meanwhile the band performs a love duet and a popular tune. The conspicuous looking guitarist-singer with his red hair, his salacious gestures, and carbolic smell soon reminds us of similar uncanny figures that already have crossed Aschenbach's path: the wanderer who stirred the protagonist's desire for an adventurous journey at the cemetery in Munich, the grotesque "false youth" on the ship to Venice, and the Charon-like gondolier. For the knowing reader, then, the leader of the ensemble is entangled in a net of symbolic references to death, sickness, and the Dionysian spirit that haunts Aschenbach's soul. With this in mind, we can now turn to the fatal encore of the performance: "a brash popular number in an unintelligible dialect and with a refrain of laughter."' The laughter soon spreads around the audience, who does not realize that it is being ridiculed by the outrageous figure:

He bent his knees, slapped his thighs, clutched his sides, he nearly exploded, shrieking now rather than laughing; he pointed to the terrace, as if there were nothing more amusing than the people laughing up there, and before long

1 Thomas Mann, Death in Venice, trans. Michael Henry Heim (New York: HarperCollins, 2004), 115 . 
everyone was laughing, everyone in the garden and on the verandah, including the waiters, lift attendants, and porters in the doorways. ${ }^{2}$

Through this act of mimetic contagion, the whole performance culminates in a Dionysian frenzy. At the same time, the uproarious laughter hints at the dissemination of the cholera disease, symbolically anticipating the fateful destiny of those present, including Aschenbach.

The performance of the street musicians marks a particularly rich and dramaturgically central scene, one in which laughter gains a "transformative power" over the members of the audience, turning them from spectators into co-participants. ${ }^{3}$ As such, it is given special weight in the two most famous adaptations of the novella-Luchino Visconti's Death in Venice (Morte a Venezia, 1971) and Benjamin Britten's eponymous opera, which premiered only two years after the film. ${ }^{4}$ Except for the "brash popular number" with the laughing refrain, Mann does not specify the repertoire performed by the band in detail. Thus, each adaptation can potentially enrich the scene by inserting preexistent or newly composed songs that provide some sort of commentary on Aschenbach's infatuation. While it has occasionally been pointed out that the songs used by Visconti and Britten ring with irony, 5 it remains to be more fully explored how both the film and the opera

2 Mann, Death in Venice, 116.

${ }^{3}$ My reading draws on Erika Fischer-Lichte's notion of performance as a liminal and transformative event from which "change to the physiological, energetic, affective, and motoric state" of the audience can emerge. Though her focus lies on performance art since the 1960 , her understanding of performance as transformation is particularly well suited to examine the novella scene and its intermedial transpositions. See her The Transformative Power of Performance: A New Aesthetics, transl. Saskya Iris Jain (London: Routledge, 2008), 177.

${ }^{4}$ Several authors deal with the novella, film, and opera in a (media-)comparative approach without commenting on the scene at hand: Ernest W.B. Hess-Lüttich and Susan A. Liddell, "Medien-Variationen: Aschenbach und Tadzio in Thomas Manns Der Tod in Venedig, Luchino Viscontis Morte a Venezia, Benjamin Brittens Death in Venice," in Code-Wechsel: Texte im Medienvergleich, ed. Ernest W.B. Hess-Lüttich and Roland Posner (Opladen: Westdeutscher Verlag, 1990), 27-54; Roger Hillman, "Deaths in Venice," Journal of European Studies 22, no. 4 (1992): 291-311; Philip Kitcher, Deaths in Venice: The Cases of Gustav von Aschenbach (New York: Columbia University Press, 2013).

5 Hans Rudolf Vaget, "Film and Literature. The Case of Death in Venice: Luchino Visconti and Thomas Mann," The German Quarterly 53, no. 2 (1980): 169. With regard to Britten's opera, Lloyd Whitesell notes the music's "mocking, streetwise commentary on the ridiculousness of [Aschenbach's] desires." See his "Notes of Unbelonging," in Benjamin Britten Studies: Essays on An Inexplicit Art, ed. Vicki P. Stroeher and Justin Vickers (Woodbridge: The Boydell Press, 2017), 226. 
convert an instance of narrated music into extended musical moments of embodied spectacle and the way in which they actualize or reconfigure the transformative space of the performance. A particular focus of this article, therefore, lies on the various manifestations of the laughing song. Originally a popular hit dating back to the early days of phonography, Mann first transcribed it from sound to text, after which it was re-rendered in sound again. ${ }^{6}$ In addition to tracing this versatile phono-graphic shifting of the song and its paroxysm of laughter, I will also situate the respective scenes within the different interpretative frames adopted by Visconti and Britten.

\section{Mann and Myth: Adapting Death in Venice}

As Linda Hutcheon reminds us, "the act of adaptation always involves both (re-)interpretation and then (re-)creation; this has been called both appropriation and salvaging, depending on your perspective." 7 With this in mind, we can deliberately bypass some of the more dismissive evaluations championing Mann's original over its allegedly inferior remediations. ${ }^{8}$ In-

\footnotetext{
${ }^{6}$ The laughing song described in the novella shows striking similarities with Berardo Cantalamessa's popular Neapolitan hit "A risa." That this song provided the template for Mann is also noted by Paolo Isotta, Il ventriloquo di Dio: Thomas Mann, la musica nellopera letteraria (Milan: Rizzoli, 1983), 160, and Fausto Petrella. The latter claims that Mann knew the song from one of his Venetian sojourns, citing a letter from Erika Mann to Mann's Polish translator, Andrzej Dołęgowski, dated 24 September 1964 as proof. See his L'ascolto e l'ostacolo: psicoanalisi e musica (Milan: Jaca Book, 2018), 167-70. In her letter, Erika Mann writes that everything depicted in the novella, including the encounter with the street singers, had really happened during the family's 1911 stay at the Grand Hôtel des Bains in Venice. With this, she echoes the well-known autobiographical account given by Mann himself in his Lebensabriß (1930). However, since Mann makes no reference to either the song or Cantalamessa, the connection remains implicit.

7 Linda Hutcheon, A Theory of Adaptation, 2nd ed. with Siobhan O'Flynn (London: Routledge, 2013), 8. Within the field of adaptation studies, Mikhail Bakhtin's notion of "dialogism" has proven especially influential in overcoming the pitfalls of "fidelity criticism." See Robert Stam, "Beyond Fidelity: The Dialogics of Adaptation" in Film Adaptation, ed. James Naremore (New Brunswick: Rutgers, 2000), 54-76 and, more recently, Dennis Cutchins, "Bakhtin, Intertextuality, and Adaptation," in The Oxford Handbook of Adaptation Studies, ed. Thomas Leitch (New York: Oxford University Press, 2017), 71-86.

${ }^{8}$ This kind of criticism was mostly directed against Visconti, whose film was seen as failing to match the complexity and subtle irony of Mann's novella. Furthermore, his equation of Aschenbach and Gustav Mahler drew strong objections. See, for example, Philip Reed, "Aschenbach Becomes Mahler: Thomas Mann as Film," in Benjamin Britten: "Death in Ven-
} 
stead, let us start by recalling a few characteristic features of both adaptations that affect the scenes at hand. In the opera, Aschenbach's experience is rendered subjectively as a sort of interior monologue. What happens on stage might be conceived as a projection from within the protagonist, made visible. 9 This change in point of view, while allowing Aschenbach to express himself in his own musical voice, entails a loss of narrational distance that Mann so carefully composed into his telling of the story. The narrator here serves as a moral compass by which Aschenbach's increasing infatuation with Tadzio is measured and eventually denounced:

What the very skillfully shaped opera story jettisons is Mann's narrator, the mocking, moralizing, explicitly ironizing voice that both describes what Aschenbach does or thinks, and tries to direct our thoughts about it. [...] The outer narrative dimension was... absorbed into the music, submerged so to speak in the musical element, and especially into the orchestra. ${ }^{10}$

Edward Said's observation provides us with a first clue regarding the role of the staged performance of the "Strolling Players" (act 2, scene 10). As we will see, the scene furnishes exactly this kind of ironic commentary in place of the absent narrator.

Another substantial change concerns the visual as well as musical spelling-out of the novella's symbolic subtext. The ominous half-mythological figures appearing in the story are impersonated by the same bass-baritone who also interprets the voice of Dionysus (besides the roles of the Hotel Barber and the Hotel Manager). Musically, this row of Dionysian harbingers is connected by a returning motif associated with percussion instru-

ice," ed. Donald Mitchell (Cambridge: Cambridge University Press, 1987), 178-83. Yet, as has also been remarked by several critics, turning the protagonist from writer to composer is more in tune with the possibilities of the filmic medium, favoring the immediacy of aural experience. See, for instance, Irving Singer, "Death in Venice: Visconti and Mann," MLN 91, no. 6 (1976): 1348-59.

9 The idea of visualizing the scenario as if it were a projection from the inside of Aschenbach's mind also informed Colin Graham's minimalist staging of the first production of Death in Venice with Peter Pears in the role of Aschenbach, which took place on June 16, 1973, at the Snape Maltings Concert Hall (Snape, UK) near Aldeburgh. See Christopher Chowrimootoo, "Bourgeois Opera: Death in Venice and the Aesthetics of Sublimation," Cambridge Opera Journal 22, no. 2 (2010): 183-85.

${ }^{10}$ Edward W. Said, "Not All the Way to the Tigers: Britten's Death in Venice," in On Mahler and Britten: Essays in Honour of Donald Mitchell on His Seventieth Birthday, ed. Philip Reed (Woodbridge: The Boydell Press, 1995), 269. 
ments creating an exotic aura of strangeness. It is first presented by the timpani, when the mysterious Traveller appears on the steps of the mortuary chapel in the Munich cemetery (act 1, scene 1). Though the motif has no fixed melodic or rhythmic structure, being varied throughout the opera, it nevertheless has a distinct shape, combining a descending scale movement with an upward leap (see example 1).

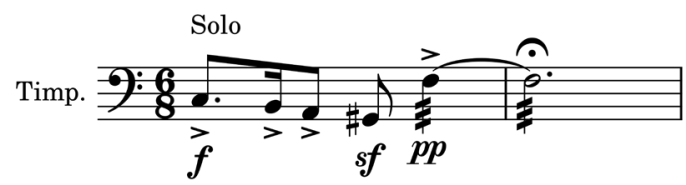

Ex. 1 Britten, Death in Venice, act 1, scene 1, rehearsal no. 13, Traveller's motif. Transcribed by permission of Faber Music, London.

After the Traveller's aria, it immediately infiltrates Aschenbach's vocal line ("Strange, strange hallucination," rehearsal no. 16), as he is inevitably drawn into the stranger's vision of a faraway tropical wilderness. In the remainder of the opera, it recurs in the vocal parts of the Dionysian characters themselves (see, for instance, the introductory phrases of the Elderly Fop and the Gondolier at rehearsal nos. 27 and 48), while various drums, including tom-toms, are usually present to remind the listener of their foreign origin.

Through musical means, then, the opera renders explicit what is only implied in the novella. This extends to the ancient gods themselves: Dionysus and Apollo both make a vocal appearance contesting Aschenbach's soul. For the silent role of Tadzio, Britten comes up with an ingenious solution. The boy and his entourage are cast as dancers as to occupy their own expressive realm, removed from that of Aschenbach. Tadzio's glittering, light-flooded sonority invokes idioms of gamelan music. As such, it is more obviously connected to the sphere of Apollo as manifested in the balletic beach episode (The Games of Apollo, act 1, scene 7), which closes the first act. ${ }^{11}$

${ }_{11}$ Before his visit to Asia in 1956, Britten had come in contact with Balinese music through the Canadian composer and ethnomusicologist Colin McPhee. In the words of Anthony Sheppard: "Britten particularly enjoyed watching the performance of the boys' gamelan, a type of ensemble initially formed by McPhee twenty years earlier. This connection between the musical exotic and homosexual opportunity is central to several of Britten's operas and 
Visconti's filmic adaptation, by contrast, eliminates the novella's mythological layers, including Aschenbach's nightmare of a bacchantic orgy signaling his complete surrender to the god of ecstasy, desire, and madness. Thus, we do not necessarily identify the guitarist-singer with the Dionysian force to which Aschenbach, in both the novella and the opera, falls prey. Yet, with his pale face and decayed teeth, he remains an unsettling appearance, combining features of death and devil. Roger Wiehe places the musicians' scene in the late-medieval iconographic tradition of the danse macabre. ${ }^{12}$ Since the dance macabre imagery became popular with the spreading of the Black Death plague in the fourteenth century, the historical connection is clear enough. However, Wiehe's reading remains largely deaf to the music and the laughing song in particular, which gains a different meaning in light of Visconti's intertextual strategy.

As many critics have noted-in some cases with a disapproving toneVisconti turned to Mann's Doctor Faustus (1947) in search of material that could be interwoven with the idea of Aschenbach as a late-romantic composer and Gustav Mahler's doppelgänger. ${ }^{13}$ To establish this link in a straightforward manner, Visconti has his protagonist arriving in Venice on a steamer named Esmeralda. Further borrowings are restricted to flashback scenes, one of which shows Aschenbach visiting a brothel. The episode is evidently a reference to the fateful syphilis infection which seals Adrian Leverkühn's pact with the devil. Another noticeable allusion to Doctor Faustus is the mocking laughter, a gesture originally associated with Leverkühn. Through its occurrences throughout the film, it links

receives its clearest expression in his final opera, Death in Venice." Revealing Masks: Exotic Influences and Ritualized Performance in Modernist Music Theater (Berkeley: University of California Press, 2001), 143. For a detailed account of Britten's compositional use of gamelan idioms, see Mervyn Cooke, Britten and the Far East: Asian Influences in the Music of Benjamin Britten (Woodbridge: The Boydell Press, 1998), 220-44.

${ }_{12}$ Roger Wiehe, "The Danse macabre as the Crucial Moment in Story and Film Versions of Death in Venice," in The Symbolism of Vanitas in the Arts, Literature, and Music: Comparative and Historical Studies, ed. Liana DeGirolami Cheney (Lewiston: Mellen, 1992), 89. The argument was first introduced in his earlier article "Of Art and Death: Film and Fiction Versions of Death in Venice," Literature/Film Quarterly 16, no. 3 (1988): 210-15.

${ }_{13}$ Vaget, for example, finds that "Visconti's toying with the Doctor-Faustus-connection strikes one as pretentious and constitutes a blunder in the conception of the film." See "Film and Literature. The Case of Death in Venice: Luchino Visconti and Thomas Mann," 172. Philip Kitcher makes a similar argument in his Deaths in Venice, 132. For a more positive assessment of Visconti's alterations, see Werner Faulstich and Ingeborg Faulstich, Modelle der Filmanalyse (Munich: W. Fink, 1977), 20-23. 
the various fateful encounters and invests the respective characters with diabolical overtones. I will come back to this point later on.

The film's soundtrack, with the Adagietto from Mahler's Fifth Symphony as center piece, plays a key role in evoking a specific turn-of-the-century ambience. While the Adagietto is more intimately tied to Aschenbach's inner state, the diegetic musical scenes add authentic local flavors through their use of popular genres, including operetta and Italian song, as well as their deliberately flawed, true-to-life sound (think of the amateurish ensemble performing a potpourri of excerpts from Franz Lehár's The Merry Widow in the hotel lobby or Esmeralda's piano playing in the brothel). With regard to the street musicians, however, Mann already provided a detailed account of the event, down to minute descriptions of lighting, poses, gestures, singing style, as well as audience reactions. For Visconti, the novella scene thus offered a sort of performance script that could be brought to life on the film screen.

\section{The Street Musician's Scene in Visconti's Death in Venice}

We enter this scene in medias res, the music having already begun. Visconti indeed takes great care to reproduce the theatrical setting as described by Mann:

The two men and two women stood by the iron post of an arc lamp, lifting their faces, white in the glare, to the large terrace, where the guests sat ready, over coffee and cold drinks, to submit to the exhibition of local color. ... The Russian family, eager to enjoy everything to the hilt, had had wicker chairs moved down into the garden so as to be closer to the performers and sat there contentedly in a semicircle. ${ }^{14}$

The camera soon cuts away from the musicians to the terrace where Aschenbach is smoking a cigarette, his facial expression revealing his tense inner state. Next, we see the reason for his anxiety. In one of his characteristic zoom shots, Visconti captures the figure of Tadzio leaning on the balustrade while turning his head twice toward Aschenbach in a self-assertive gesture..$^{15}$ The second time, the camera comes to rest on a medium close-up

${ }^{14}$ Mann, Death in Venice, 108-9.

15 On the narrational function of the zoom, see Michael Wilson, "Art is Ambiguous: The Zoom in Death in Venice," Literature/Film Quarterly 26, no. 2 (1998): 153-56. 
of him, just as the band finishes its casual entrance number. Throughout the scene, there are several synch points between the image and the music, lending a rhythmical flow to the editing.

Downstairs the band continues its program with the popular tune "Chi vuole con le donne aver fortuna" ("He who wants to be lucky with women") by the Neapolitan singer-songwriter Armando Gill, who was famous in Italy during World War I. The lyrics abound with irony when seen in light of Aschenbach's situation. First, the heteronormative framework of the song reminds us of his "aberrant" desire. Second, the light-hearted approach to love that the singer advocates stands in obvious contrast to Aschenbach's desperate and insatiable yearning. ${ }^{16}$

At the beginning of the song the band walks up to the terrace (figure 1). The guitarist first approaches Aschenbach and then continues to walk around the other guests, including Tadzio's family. ${ }^{17}$ His mother is repelled by the unpleasant appearance of the man but tries to keep her composure. Tadzio, however, does not attempt to hide his repulsion: he backs away from the guitarist's approaches and seeks Aschenbach's eyes. For a brief, intense moment, the latter returns the gaze by looking directly into the camera, which has taken Tadzio's position. In granting this intimate encounter (if only implicitly), Visconti again takes a liberty with the novella. In the source-text, Aschenbach strictly avoids meeting Tadzio's eyes out of fear of being exposed. With an inviting gesture, the guitarist holds his arm out in front of Aschenbach as he sings the last line of the fourth stanza "come mi attira il letto di quel fiume" (How the bed of that river entices me.) Not coincidentally, this allusion to death as relief from suffering is directed at Aschenbach. Tadzio's mother soon becomes aware of the delicate constellation between the older man and her son and casts a watchful eye on both.

${ }^{16}$ The song tells the story of a man who temporarily ponders killing himself after having learned of the suicide of his former lover. However, the last stanza concludes: "Vorrei morire per non soffrire, | ma il cuore si ribella, | dice: 'perché? | tante ce n’è! | La troverai più bella!"” (I want to die so I won't suffer anymore | but the heart refuses, | saying: "Why? | There are so many [women]! | You will find a more beautiful one!").

${ }_{17}$ In this the film deviates from the scene in Mann's novella, where the whole ensemble remains separate from the audience on the terrace until the guitarist comes forward and starts collecting the money. 


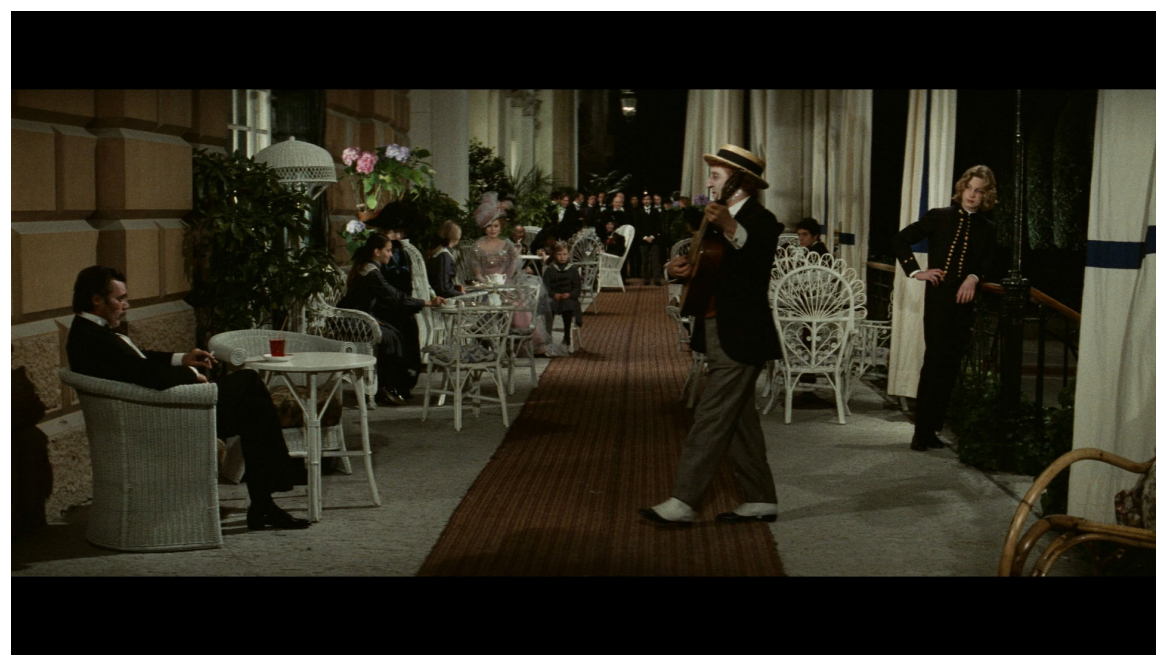

Fig. 1 Visconti, Death in Venice, the guitarist visits the terrace

\section{The Strolling Players Scene in Britten's opera}

In Britten's opera, the corresponding staged performance (act 2, scene 10) opens with the announcement of the Strolling Players. While Mann himself speaks of "Straßensänger" (street singers) or "Bettelvirtuosen" (beggar virtuosos), the somewhat antiquated term referring to a traveling theater group is introduced by Helen Tracy Lowe-Porter in her 1928 translation of the novella that Britten and his librettist, Myfanwy Piper, used for their adaptation. ${ }^{18}$ Differing from the original ensemble, the group here consists of a boy, a girl, the Leader, and two acrobats who mime several instruments (i.e., flute, guitar, and trumpet). At the beginning of the scene, the solo timpani’s repeated minor sixth leap $\left(\mathrm{G} ¥ 2-\mathrm{E}_{3}\right)$, accompanied by a swirling triplet figure in the clarinet, immediately recalls the Traveller's motif. The musical texture with the ostinato scale passages in the piano is similar to the one that Britten employs for the hotel in scene 4 of act 1 (rehearsal no. 66). Having tied the identity of the Leader to earlier scenes of the opera,

${ }_{18}$ Peter Evans, The Music of Benjamin Britten (Oxford: Clarendon Press, 1996), 524. Lowe-Porter's translation was instrumental in introducing Death in Venice to an English-speaking public. In 1925, she had been granted exclusive rights to translate the works of Mann from German into English by Alfred A. Knopf. For a critical study of the novel-to-opera adaptation of Death in Venice, see Clifford Hindley, "Contemplation and Reality: A Study in Britten's Death in Venice," Music \& Letters 71, no. 4 (1990): 511-23. 
the timpani motif conspicuously reappears at the end of the performance when the character finishes his "Laughing Song" with a "wild gesture" (rehearsal no. 257). While the hotel staff ushers the guests to their tables ("This way for the players, Signori!"), the latter respond with a brief chorus commenting on the show they are about to see. Its parodistic technique is explicitly signaled by the line "with old songs new turned." Through this extended introduction Britten prepares the listeners for the ensuing performance that actually unfolds as a play-within-a-play, making Aschenbach the prime target of mockery.

The first number "O mio carino" is a waltz-duet sung by the Girl and the Boy, ${ }^{19}$ while the second piece "La mia nonna" marks the entrance of the sinister Leader. Both numbers are parodies of Italian folk songs. "O mio carino" is based on "Giovanottino, mi garbate tanto" for voice and piano by the composer and band leader Mario Ferradini (1863-1907). ${ }^{20}$ It was published as sheet music in 1903 by the Florentine publisher Genesio Venturini and subsequently recorded in various arrangements by several different singers. While the precise origins of this popular Tuscan folk song remain unclear, it appears in several anthologies dating from the mid-nineteenth century at the earliest. ${ }^{21}$ Piper translated Ferradini's version into English and provided a few additional verses, exposing Aschenbach as the object of ridicule ("For you forgotten honour, work, and duty"). Besides, the song's religious rhetoric ("How shall I save my soul, l'anima mia?") adds quite naturally to the mocking irony of the scene in suggesting that Aschenbach's relationship is morally reprehensible.

The parodistic tone is further enhanced by Britten's burlesque arrangement and its sudden harmonic shifts (example 2). Musically, the verses are grouped in six pairs, each featuring the same melody closely modelled after the first five bars of Ferradini's song. The oom-pah-pah accompaniment of the waltz is supplied by timpani, strings, and harp. Throughout the

${ }_{19}$ "O mio carino," as well as the first version of the Leader's song which Britten had to drop due to copyright issues, were already included in his sketchbook for the opera. See Colin Matthews, "The Venice Sketchbook," in Mitchell, Benjamin Britten: "Death in Venice," 56.

${ }^{20}$ See Andrea Sessa, Il melodramma italiano, 1861-19oo: dizionario bio-bibliografico dei compositori (Florence: Olschki, 2003), 188.

${ }^{21}$ See Canti popolari toscani, corsi, illirici, greci, raccolti e illustrati da N. Tommaseo con opuscolo originale del medesimo autore, 4 vols. (Venice: Girolamo Tasso, 1841), 1:104-9; Canti popolari toscani: raccolti e annotati da Giuseppe Tigri (Florence: Barbera, 1856), 80 as well as Canti popolari toscani, scelti e annotati da Giovanni Giannini (Florence: Barbera, 1902), $143-44$. 
song, the timpani plays a rhythmicized E pedal tone occasionally dropping "false" accents on the weak second beat. While the key signature indicates A major, the initial melodic ascent introduces $B$ major and then turns to the tonic via a lowered D5 ("near me").

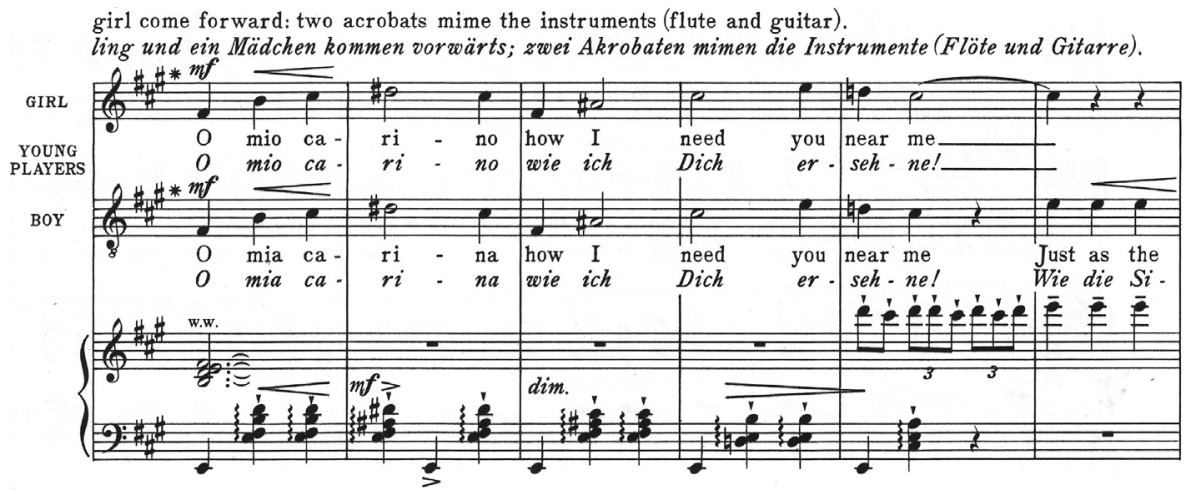

Ex. 2 Britten, Death in Venice, act 2, scene 10, "O mio carino," beginning, vocal score. Reproduced by permission of Faber Music, London.

A similar shift occurs in the harmonization of the second verse "Just as the Siren needs the salt sea water," which-after a succession of dominant seventh chords $\left(\mathrm{B}^{7}, \mathrm{~F}^{7}, \mathrm{E}^{7}\right)$ - plunges into the relative $\mathrm{F} \#$ minor. The characteristic waltz accompaniment is temporarily suspended when Aschenbach and Tadzio appear on stage (rehearsal no. 241). Right at this moment, celli and bassoons pick up the so-called "longing motif" associated with Aschenbach's amatory fixation. A row of shimmering chords by vibraphone and glockenspiel-Tadzio's signature sound-signals the visible presence of the boy on the terrace. In contrast to the novella and film scene, in which the exchange of glances establishes a more intimate connection between the two (Tadzio actually seeks the eyes of the older man), the opera keeps them at a safe distance. However, as Philip Rupprecht aptly observes, there is a gaze-like quality about the boy's musical presence in that its vibrant glistening texture and arrested temporality seem intrinsically linked to Aschenbach's perception. Referring to the latter's first catching sight of the boy (act 1, scene 4), Rupprecht notes:

Suddenly, everything gleams - the timbre of the vibraphone theme itself, and the iridescent cluster-chords beneath. The freezing of the musical action here 
is a cessation of harmonic motion. ... Once Tadzio has gone, Aschenbach, as if released from hypnosis, reverts to the rational mood (and dry timbres) of his piano recitatives. ${ }^{22}$

Through what he calls Aschenbach's "sonic gaze," 23 Tadzio is rendered an object of remote exotic fascination and sensory appeal.

From this point on the scene gets more and more oppressive as a brash trumpet signal announces the entrance of the Leader. While the lyrics of his number "La mia nonna always used to tell me" are inspired by the popular song "La mia mamma mi diceva," the punctuated melody itself (example 3) alludes to the beginning of the Piedmontese song "Le tre colombe." ${ }_{24}$ Compared to the preceding duet and its subtle innuendos, the Leader's solo-though not explicitly engaging with Aschenbach-strikes an uncannier note. On the surface, the song pokes fun at the infidelity of women, but the musical setting adds a grim undertone to the whole, thereby exposing the threatening character of the figure. Each of the three stanzas is set in a different key according to a sequence of rising half steps $\left(\mathrm{G}_{4}-\mathrm{G} \sharp 4-\mathrm{A}_{4}\right)$, with the incipit played by the solo trumpet and immediately taken up by the vocal line. Otherwise, the instrumentation is utterly sparse, featuring a small drum as characteristic token of the Dionysian musical exoticism, "thrummed" pizzicato strings and piano. The latter provide a series of brusque, dissonant arpeggios accentuating the Leader's repeated falsetto line "Sono tutte traditore!" like an out-of-tune guitar. ${ }^{25}$ The first of these disruptions (one measure before rehearsal no. 244) occurs with a bitonal harmony mixing $\mathrm{C}$ major with $\mathrm{Ab}$ major. The vocal melody of "sono tutte vagabonde" further adds to the chromatic harshness through its modal inflection. The effect thus created is less comical than unsettling.

${ }^{22}$ Philip Rupprecht, Britten's Musical Language (Cambridge: Cambridge University Press, 2001), 269.

${ }^{23}$ Rupprecht, Britten's Musical Language, 267.

${ }^{24}$ See Paul Banks, ed., Benjamin Britten: A Catalogue of the Published Works (Aldeburgh: Britten-Pears Library, 1999), 145. Bank lists the song under the title "S'ai son tre colombe bianche."

${ }^{25}$ The falsetto voice is also used to characterize the Elderly Fop in the boat scene of act 1 , scene 2 . 

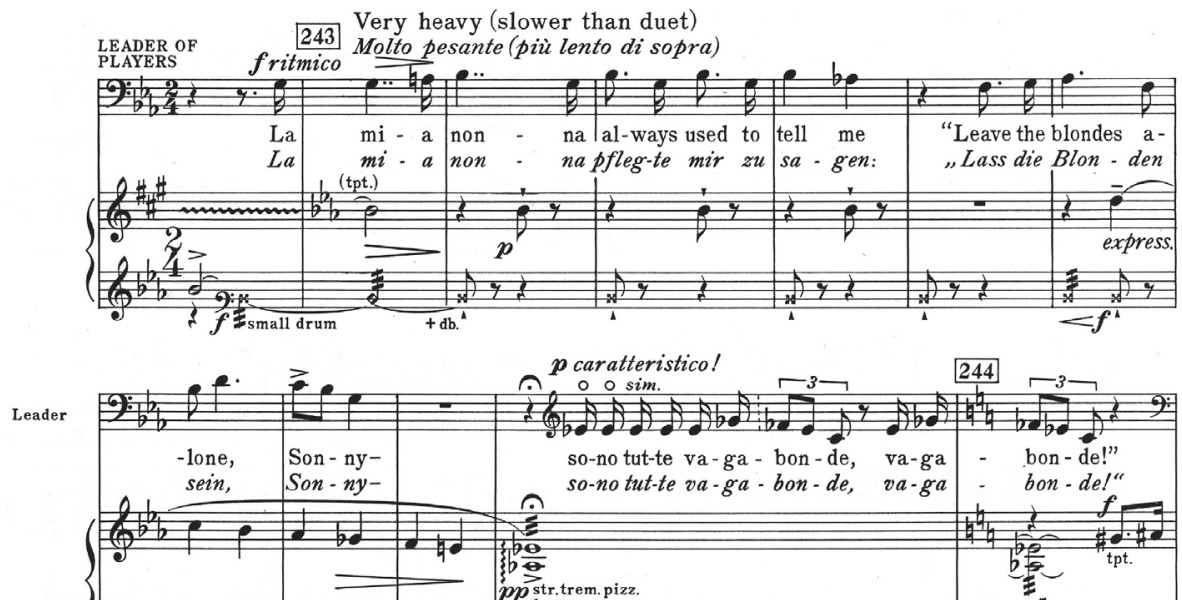

Ex. 3 Britten, Death in Venice, act 2, scene 10, "La mia nonna," beginning, vocal score. Reproduced by permission of Faber Music, London.

The same can be said of the closing stretta marked "Gaily," in which the Leader repeatedly blares out his sarcastic punch line "So I shall never be able to marry-Evviva la libertà!" The instrumentation now comes to include a tuba, whose dark and menacing tone carries associations of death and disease, as we will see shortly. ${ }^{26}$

As in the novella and the film, Aschenbach inquires about the disinfection of Venice when the Leader collects money from the guests. Here, Britten recalls another prominent motif signaling the eminent threat to which Aschenbach remains willfully oblivious. It consists of four notes combining a descending whole tone and a half tone step separated by a rising major third, and is most commonly referred to as a sounding symbol of the plague. ${ }^{27}$ However, tracing its deployment in the opera, it becomes clear that it has thematically intertwined connotations, ranging from Dionysian enchantment and desire to death. Britten first introduces the motif at the beginning of the Traveller's aria, set to the words "Marvels unfold!" (rehearsal no. 14). Its mysterious timbre is produced by the overlapping of sustained notes in the horn and bassoon, which also features a trill. At the end of act 1, in the section preceding the love vow, the motif now resounds

26 See Christopher Palmer, "Britten's Venice orchestra," in Mitchell, Benjamin Britten. "Death in Venice," 137-38.

27 See Evans, The Music of Benjamin Britten, 526. 
in the low register of the bassoon (six measures after rehearsal no. 185), semantically enriched by undertones of madness and sickness as Aschenbach rebukes himself for succumbing to the illusion of befriending Tadzio ("The heat of the sun must have made me ill"). However, it is only with his following visit to the Hotel Barber's shop (act 2, scene 8) that the motif's linking with the plague becomes the predominant meaning. When the chatty Hotel Barber-who is part of the Dionysian ensemble-asks Aschenbach if he feared the sickness spreading in Venice, the latter spontaneously expresses his irritation: "Sickness! Sickness! What sickness?" (rehearsal no. 198), while the tuba repeats the motif twice in a row $\left(\mathrm{D}_{2}-\mathrm{C}_{2}-\mathrm{E}_{2}-\mathrm{E}_{\text {,2 }}\right)$. In its accumulation of meanings, the musical theme thus serves as a symbolic nexus connecting the spread of the cholera with its mythical correspondence-that is, the coming of the "stranger god." ${ }^{28}$ The dialogue between Aschenbach and the Leader (rehearsal no. 248) is interspersed with pungent cluster versions of the motif played by the flute, oboes, clarinets, and a muted trumpet. At this point it has taken on an overtly menacing tone belying the Leader's explanations about the disinfection measures.

Rather than providing a mere comical insert, the performance of the Strolling Players is punctuated by motivic references. The orchestra, while supplying the music for the pantomimed instrumental playing on stage, also acts as a narrating voice, underpinning and connecting key moments of the unfolding drama. Though the songs themselves are rooted in popular Italian folk music and thus add couleur locale to the performance, Britten's parodistic treatment with its harmonic tensions and characteristic instrumentation serves to integrate them into the musical language of the opera as a whole..$^{29}$

${ }^{28}$ In the novella, Dionysus is referred to as the "stranger god" due to his foreign Asian origins. Thus, his pursuing of Aschenbach is symbolically connected to the spread of Asian cholera into Europe.

${ }^{29}$ Drawing on Bakhtin's notions of "dialogism" and "polyphony" in the novel, Luca Zoppelli argues that stage music with its diverse musical idioms and genres contributes to the "dialogical" character of operatic discourse. The characters speak for themselves in their own musical voice and thus become emancipated from the style and narrational control of the author. See "'Stage Music' in Early Nineteenth-Century Italian Opera," Cambridge Opera Journal 2, no. 1 (1990): 29-39. In the case of Britten's Death in Venice, however, the composer's voice closely aligns itself with Aschenbach. The musical "I" of Aschenbach could be said to present a plural, fragmented consciousness in that it is infiltrated or populated by multiple, opposing voices, each represented through a specific musical idiom, such as the sober voice of reflection articulating itself in the recitativic parts accompanied by the piano, the Apollonian voice embodied in the gamelan-inspired orientalism pertaining to Tadzio, and the more threatening vocal realm of the Dionysian. 


\section{The Laughing Songs of Death in Venice}

Let us now turn to the climax of the performance-the ominous laughing song. In Mann's literary rendering, the laughter, as part of the song's refrain, has an ambiguous character. In its rhythmically ordered structure, it constitutes an artificial musical device. Yet, when uttered by the guitarist, the laughter gains a seemingly "lifelike" quality ready to cross the boundaries of the performance itself. The breaking of the fourth wall occurs gradually in the act of singing, as the stylized laughter of the refrain veers into plain mockery aimed at the clueless audience.$^{30}$ In an ingenious manner, Mann fleshes out this liminal moment when the guitarist breaks into spasm losing control over his body and voice:

he would choke, his voice would falter, he would press his hand to his mouth and hunch his shoulders till at just the proper moment an unbridled laugh would break, burst, bellow out of him and with such verisimilitude that it had a contagious effect on the audience, causing an objectless, self-perpetuating hilarity to take hold on the terrace as well.$^{31}$

In its display of bodily excess, the scene exhibits a "carnivalesque" quality. Social etiquette is finally overthrown, as the audience falls into a state of intoxication. When the performance has finished, the guitarist sticks his tongue out at them, a gesture that explicitly symbolizes the inversion of hierarchy.

In the novella, music and sound are associated with the foreign sphere of Dionysus. As such, they border on the chaotic, the sexual, and the incomprehensible-from the strange, inarticulate murmuring of the gondolier and the alien-sounding idiom of the laughing song to the overpowering sonic assault of the Bacchantic round dance that Aschenbach

${ }^{30}$ As Manfred Dierks pointed out, it is Euripides' late tragedy The Bacchae, in which Dionysus triumphs over King Pentheus who refuses to worship him, that served as a model for the novella and for this scene in particular. In the play, the god comes to Thebes in human disguise, accompanied by a traveling band of Bacchantes from Asia. When the messenger announces Pentheus' death, the chorus mocks him with a foreign-sounding song of triumph. See Dierks, Studien zu Mythos und Psychologie bei Thomas Mann. An seinem Nachlaß orientierte Untersuchungen zum «Tod in Venedig», zum «Zauberberg» und zur «Joseph»-Tetralogie (Bern: Francke, 1972), 21-25.

${ }^{31}$ Mann, Death in Venice, 116. 
joins in his dream. ${ }^{2}$ For Britten's librettist, however, the "unintelligible dialect" of the song posed a problem of its own. For the Leader's second number to fit into the trajectory of the scene and develop its full dramatic potential on stage the lyrics had to be intelligible or least contain some allusive expressions:

\begin{abstract}
The real facer was the laughing song. What language could it be written in? Though incomprehensible, words here and there ought to be understood. I toyed with macaronics, using Italian, French and English or German perhaps, but my Italian was not good enough to play about with, my German almost nonexistent and there seemed no excuse for French. I thought of nonsense verse but even if it had been possible, the Englishness of it would have been unacceptable. At last it occurred to me that the Venetian dialect would have been incomprehensible to the Hotel Guests, Aschenbach included, [...]. So with the help of a book of old Venetian ballads and nursery songs ... I wrote a version of what was eventually used..$^{33}$
\end{abstract}

With the draft in hand, Piper eventually consulted an Italian language expert who helped produce a more refined version in proper Venetian dialect. The refrain itself, however, was kept in English. The fact that Mann himself hints at the Neapolitan background of the guitarist ("He seemed less the Venetian type than of the race of Neapolitan comedians") is strangely ignored. ${ }^{34}$

The "Laughing Song" of the opera (figure 2) consists of five stanzas comprising rhetorical questions such as "Do roses flower in the midst of ice" answered by the chorus "How ridiculous you are!" While the first two stanzas present paradoxical phenomena, the following two question amorous relationships between young and old as if they were paradoxical, too. The tone of mockery is much more personal than in the novella as the Leader seems to be quite aware of Aschenbach's passion for Tadzio and his desolate condition ("Can a tired bird whistle"). One could indeed speculate whether the whole scenario, as conceived by Piper and Britten, arises from the guilt-ridden consciousness of the old man who punishes himself for his illicit feelings. On the other hand, however, the lyrics also contain an element

${ }^{32}$ See Marc A. Weiner, "Silence, Sound, and Song in Der Tod in Venedig: A Study in Psycho-Social Repression" Seminar: A Journal of Germanic Studies 23, no. 2 (1987): 137-55.

${ }^{33}$ Myfanwy Piper, "The Libretto," in Mitchell, Benjamin Britten. "Death in Venice," 52.

${ }^{34}$ Mann, Death in Venice, 112. 
of concealment, since they avoid any obvious reference to the homoerotic nature of Aschenbach's feelings.

Fiorir rose in mezo al giasso

e de agosto nevegar.

How ridiculous you are!

Trovar onde in terra ferma e formighe in mezo al mar. How ridiculous you are!

Giovinoto che a na vecia tanti basi ghe vol dar.

How ridiculous you are!

Bella tosa che se voia co un vecio maridar.

How ridiculous you are!

Oseleto un fià stracheto che sia bon da sifolar.

What a lot of fools you are!
Do roses flower in the midst of ice.

Does snow fall in August.

(Chorus)

Are there waves upon the dry land, or ants in the middle of the sea.

(Chorus)

Does a young man want to give an old woman kisses.

(Chorus)

Does a pretty girl wish to marry an old man.

(Chorus)

Can a tired bird whistle.

(Chorus) $^{35}$

Fig. 2 Death in Venice, Piper's "Laughing Song," lyrics

For the composer, the idea of mocking laughter provided an opportunity to exploit a genuinely operatic effect, as for example Carl Maria von Weber in his Freischütz and Verdi in Falstaff had done before. While one might have expected to find the ominous "plague motif" integrated into the musical texture, Britten opts for another, less obvious solution that gives the song a completely different twist. His "Laughing Song" sounds like a dull nursery rhyme accompanied by a dreary change of chords in horns, clarinets, and bassoons imitating a concertina (example 4), while the vocal part is marked "con voce infantile."

${ }^{35}$ The English translation is included in the printed full score. See Benjamin Britten, Death in Venice, an opera in two acts, op. 88 (London: Faber Music Limited, 1979), appendix. 
and starts the "Laughing song". ASCHENBACH and TADZIO never join in the laughter.

252 Slow Lento $(d=58)$

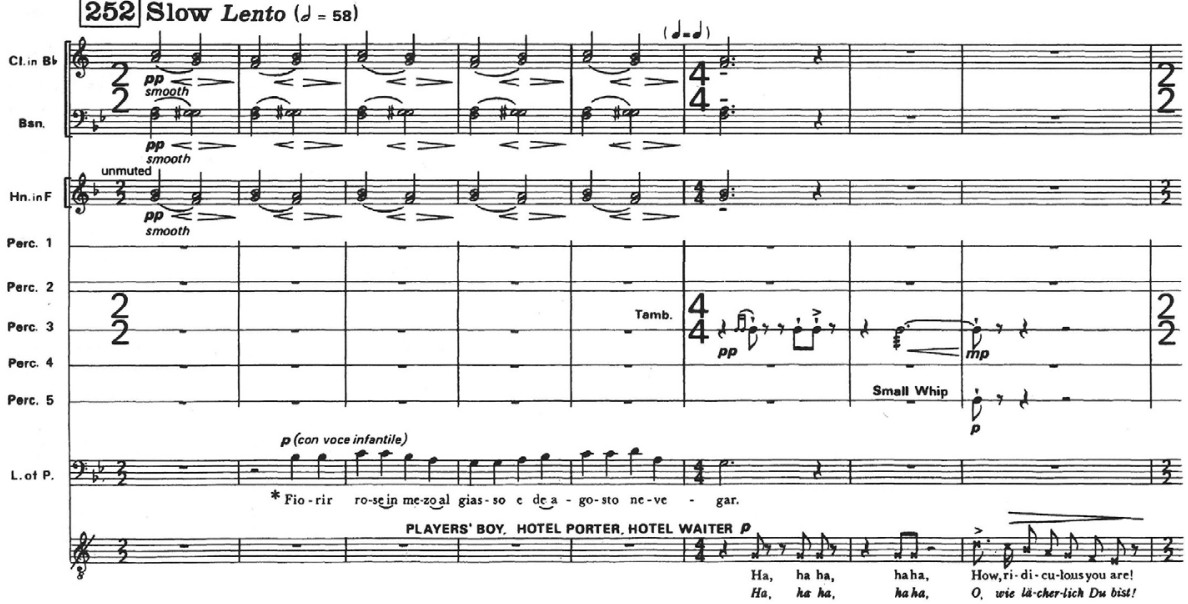

Ex. 4 Britten, Death in Venice, "Laughing Song," beginning. Reproduced by permission of Faber Music, London.

Following the initial stanza, the boy, a waiter, and the hotel porter first join in with a rhythmically patterned laughter segued into the refrain. The next burst of laughter-the group is now enlarged by two hotel guests-interrupts the second stanza in a hocket-like manner with the voices imitating each other. The laughing chorus gradually builds in intensity as well as rhythmic complexity as soprano and alto voices are further included. Throughout the song, the vocalized laughter is doubled by percussion instruments: tambourine, side drum, tenor drum, bass drum, as well as a small and large whip. While the drums recall once more the Dionysian sonic realm, the whips add another characteristic component that lends an aggressive tone to the Leader's performance. Britten uses them only in this particular song, thus casting a special meaning to them. As a symbol of dominance, the whip is strongly reminiscent of another ominous character-i.e., the mesmerist Cavaliere Cipolla from Mann's novella Mario and the Magician (1930). ${ }^{36}$ In his show, the magician exercises power through the hissing tone of his riding whip, which can induce as well as remove trance-like states in members of the audience:

${ }^{36}$ Britten likely knew the story as it was included in the 1954 Vintage Books edition "Death in Venice" and Seven Other Stories (translated by Lowe-Porter) which can be found at the Britten-Pears Library in his house in Aldeburgh (ref. 1-9601308). 
Two main features were constant in all the experiments: the liquor glass and the claw-handled riding-whip. The first was always invoked to add fuel to his demoniac fires; without it, apparently, they might have burned out. On this score we might even have felt pity for the man; but the whistle of his scourge, the insulting symbol of his domination, before which we all cowered, drowned out every sensation save a dazed and outbraved submission to his power. ${ }^{37}$

In the "Laughing Song," too, one gets the impression that the audience is under the spell of the Leader, especially when looking at the climactic coda (two measures after rehearsal no. 255). Here, the sound of the two whips is especially prominent (example 5).

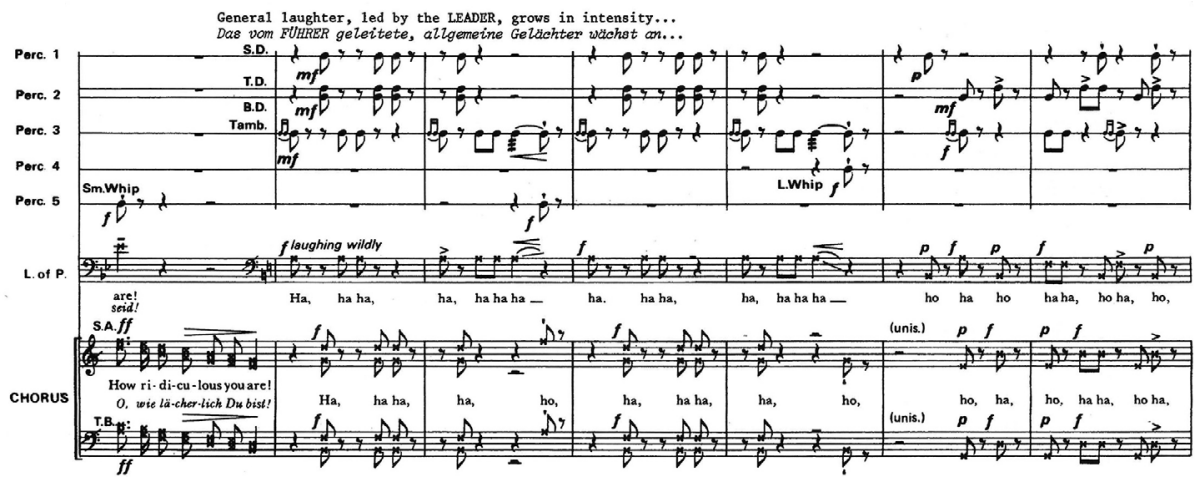

Ex. 5: Britten, Death in Venice, "Laughing Song," coda. Reproduced by permission of Faber Music, London.

Just before the beginning of the coda, the Leader suddenly changes the refrain line into "What a lot of fools you are!" thereby insulting his obedient audience. He then starts to take control over the laughing chorus who follows his vocal utterances in close imitation. Alternately, small and large whips accentuate the high points of his rising glissandi. These become more and more strident until the Leader stops the escalating laughter by means of a single gesture. It is accompanied by the cracking of both whips at once (rehearsal no. 256), as if to release the hotel guests from their spellbound state. The transgressive element of the laughing song that we encountered in Mann's novella is thus transformed. Instead of an uncontrolled outbreak

37 Thomas Mann, Mario and the Magician and Other Stories, trans. Helen Tracy Lowe-Porter (London: Vintage, 1996), 146. 
of natural laughter, here we witness an uncanny act of will control exerted by the savage Leader. Though the whips are not visible on stage, their sound exposes the violent nature of the scenario.

Compared to Britten's musical realization, the laughing song heard in Visconti's film comes much closer to the "brash popular number" described in the novella. Surprisingly close, one could say, since it unveils and gives a tangible presence to Mann's own source. In 1895, during the early days of phonography, the Neapolitan singer and actor Berardo Cantalamessa came across a popular American tune called "The Laughing Song" composed and recorded numerous times by the Afro-American singer George W. Johnson. ${ }^{38}$ Discovered as a New York street artist with a penchant for whistling, he began to produce recordings on wax cylinders for several companies, including the New York Phonograph Company, the New Jersey Phonograph Company, and Columbia in 1890. Both "The Laughing Song" featuring Johnson's distinctive, musically-timed laughter and another tune called "The Whistling Coon" established his pioneering role as the first black voice to gain fame in the nascent industry. ${ }^{39}$ His enormous success, however, stemmed not only from the catchy melodies themselves but also from the then popular image of the "coon" (i.e., a racialized portrayal of the black man as the biglipped, lazy fool that became a standard trope of the so-called "coon song)."40 Placing "The Laughing Song" in the wider context of early recording, Jacob Smith further emphasizes that "the laugh was a significant and powerful index of presence for the first audiences of prerecorded performances." ${ }^{31}$ As a case in point he cites the peculiar genre of the laughing records that flourished in the first decades of the twentieth century. They feature deliberately flawed performances of classical music-usually in the form of a vocal or an instrumental solo containing some mistake-interrupted by a sudden breaking up in laughter from a member of the audience. This, in turn, affects the musician who bursts out in laughter as well. This idea of a reciprocal in-

${ }^{38}$ Some of Johnson's recordings-including different versions of "The Laughing Song"can be found and listened to in the Collected Works of George W. Johnson, Internet Archive, added February 20, 2004, https://archive.org/details/GeorgeWJohnson.

${ }^{39}$ For a more detailed account of Johnson's life and career, see Tim Brooks, Lost Sounds: Blacks and the Birth of the Recording Industry, 1890-1919 (Urbana: University of Illinois Press, 2004), 15-71.

${ }^{40}$ The coon song emerged in the tradition of the minstrel shows, where it was typically performed by white men in blackface. In 1894, Johnson himself joined a group of performers named the Imperial Minstrels who recorded miniature versions of minstrel shows on cylinder.

${ }^{41}$ Jacob Smith, Vocal Tracks: Performance and Sound Media (Berkeley: University of California Press, 2008), 19. 
fection between performer and audience marks a striking parallel to Mann's novella scene hinting at its own intermedial character.

The song that comes closest to Mann's description, however, is not Johnson's original but its Neapolitan parody—namely, Cantalamessa's "'A risa." How the Italian singer came to adapt the song in 1895 is recollected by his partner Nicola Maldacea, another famous Neapolitan comedian:

On a certain day, after a rehearsal at the Salon, we stopped in the Galleria at a shop by the side of the Crociera.... For the first time there were phonographs in Naples, a very recent invention... The major attraction was a popular song by a black North American artist. I don't remember the name of the song. I know only that it created in Cantalamessa and me a very great impression because it communicated an irresistible joy. The singer laughed at the sound of the music, and his laughter was so spontaneous and so entertaining that he [Cantalamessa] was prompted to imitate it. ${ }^{42}$

By 1895, Johnson's cylinder recordings had made it to Italy, where they were showcased by exhibitors to a paying public. ${ }^{43}$ Cantalamessa was not the only one to seize upon the comic potential of Johnson's song by producing his own version of it (figure 3), but he was one of the few Neapolitan artists at the time whose voice was preserved on cylinder and disc. In August 1901, he recorded several solo and duet numbers, including "A risa" on Edison cylinders with the Milan-based Anglo-Italian Commerce Company. ${ }^{44}$ The

42 "Un certo giorno, dopo la prova al Salone [Margherita], ci fermammo in Galleria in un negozio di quel lato della Crociera, [...]. Vi erano esposti, per la prima volta a Napoli, i fonografi, recentissima invenzione. ... La maggiore attrattiva era costituita da una canzonetta in inglese, speciale fatica di un artista moro del Nord America. Non ricordo il nome della canzonetta. So solo che essa produsse in Cantalamessa e in me una grandissima impressione, perché di allegria irresistibilmente comunicativa. Quel cantante rideva a suon di musica, e la sua risata era così spontanea e così divertente che si era invitati senz'altro imitarlo." Nicola Maldacea, Memorie di Maldacea: vita, morte e resurrezione di un Lazzaro del XX secolo (Naples: F. Bideri, 1933), 141-42; the English translation is taken from Simona Frasca, Italian Birds of Passage: The Diaspora of Neapolitan Musicians in New York (New York: Palgrave Macmillan, 2014), 84.

${ }^{43}$ That Johnson's recordings reached an international market is indicated on the cover of the sheet music for the "Laughing Song," published in 1894. The advertising line reads, "Over 50,000 records up to date for phonograph use all over the world." Quoted in Brooks, Lost Sounds, 40.

${ }^{44}$ Anita Pesce, La sirena nel solco: origini della riproduzione sonora (Naples: Guida, 2005), 44-45. On the early international distribution of Neapolitan songs, see her chapter "The Neapolitan Sound Goes Around: Mechanical Music Instruments, Talking Machines, and Neapolitan Song, 1850-1925," in Neapolitan Postcards: The Canzone Napoletana as Transnational Subject, ed. Goffredo Plastino and Joseph Sciorra (Lanham: Rowman \& Littlefield, 2016), 45-72. 
90

PERFORMANCE AS TRANSFORMATION

following year another version of his "canzonetta eccentrica," now under the Italianized title "La risata," ("The laugh") appeared on shellac disc (7 8rpm). It was issued by the International Zonophone Company, then the biggest competitor of the Berliner Gramophone Company.
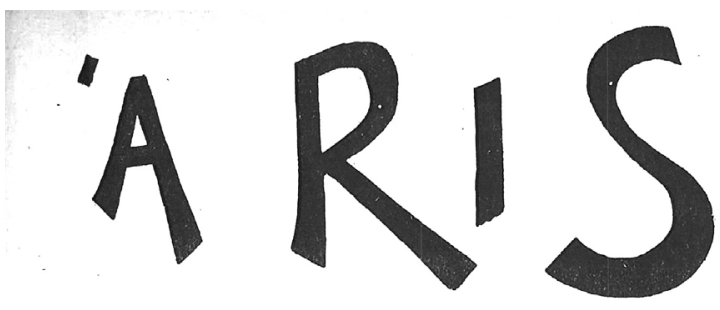

A12/281

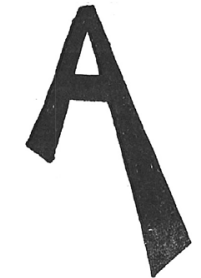

( $R E D I T E \ldots$ )

gnzonetTx EgcenTrica

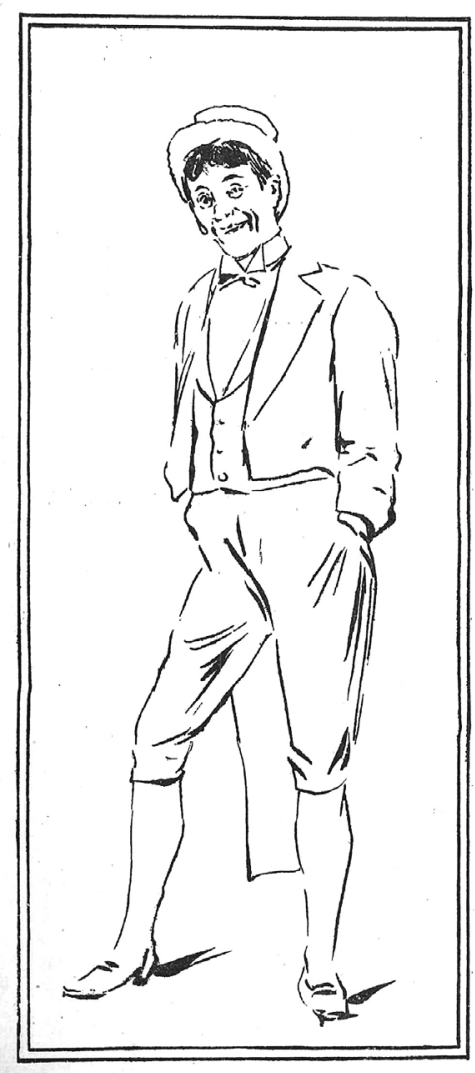

882 Fr. 3.

G. SANTOUIANN I

Editore-Stampatore NAP OUI

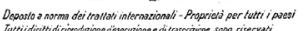

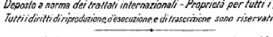

(Copyright 1899. by G.Santojanni.) (Printed in Italy) DEPOSITARIO ESCLUSIYO PER LA FRANCIA LE COLLIE EPELBELGIO GALTON GROSS 10. Rue de Mogador [prat [0píu]

SOUND STAGE SCREEN 2021/2 
2

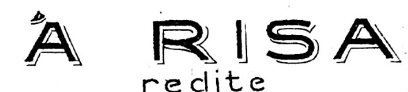

Canzone sentimentale eccentrica
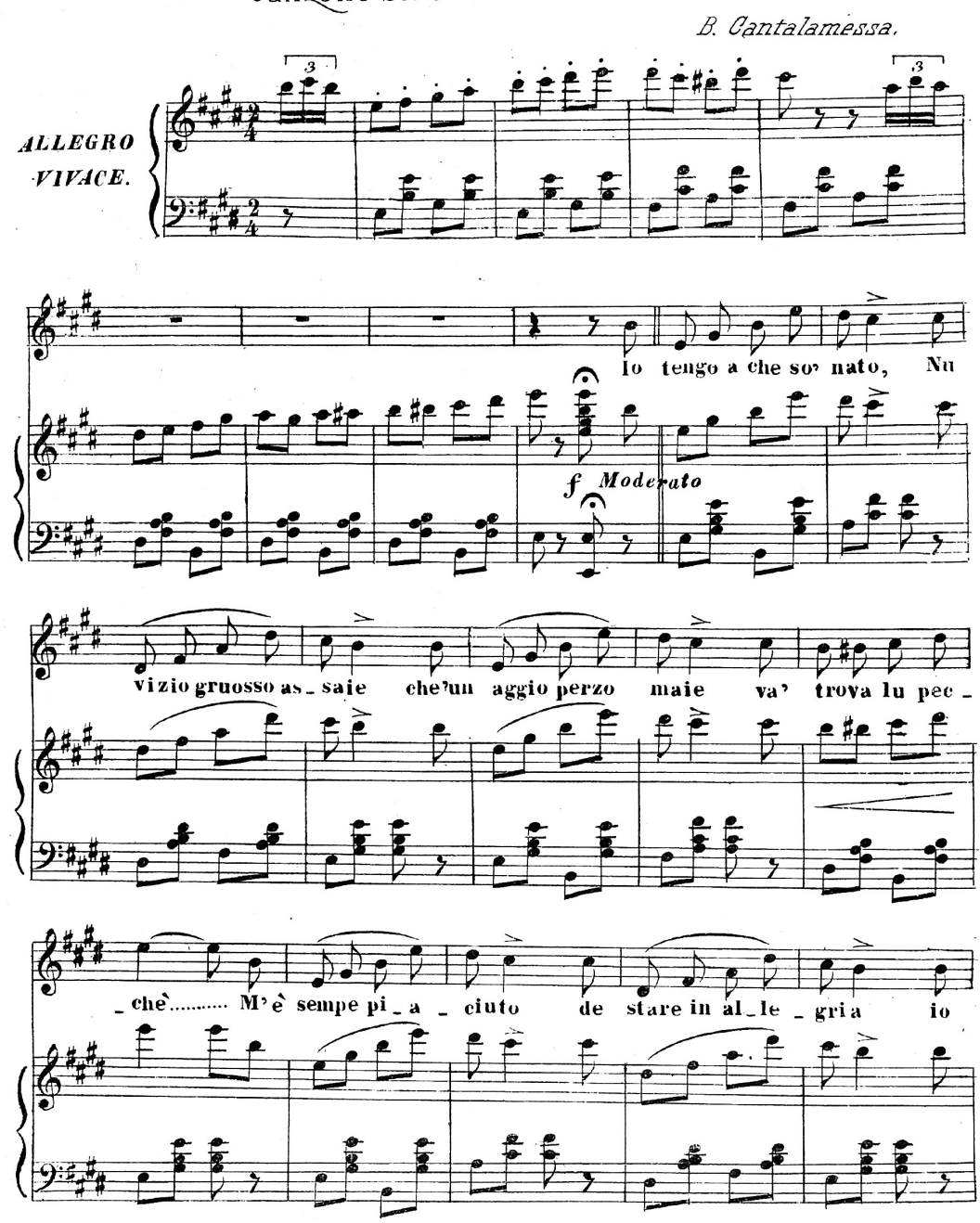

Fig. 3 Cantalamessa, "'A risa", cover of sheet music and first page

Around the mid-189os Thomas Mann was living in Italy, where he visited Rome, Palestrina, Venice, and Naples in December of 1896. If he ever saw one of Cantalamessa's performances during this stay remains unclear, but it seems more than likely that he heard the song in one form or anoth- 
er and later incorporated it into his novella. ${ }^{45}$ For Visconti the connection must have seemed evident, all the more so since "A risa" can be considered a popular classic. Due to its hilarious spirit, it works perfectly in the film. When the guitarist starts singing the song, it quite naturally excites a mindless gaiety among the audience. If we consider the lyrics (figure 4), ${ }^{46}$ the function performed by the laughter is that of a comic catharsis. In the context of the scene, however, this idea is ironically inverted. Instead of becoming liberated through laughter, the audience is infected by it and thus symbolically rendered sick.

\begin{tabular}{|c|c|}
\hline $\begin{array}{l}\text { Io tengo 'a che sò' nato, } \\
\text { 'nu vizio gruosso assaje, } \\
\text { nun l'aggio perzo maje, } \\
\text { va' trova lu ppecché! } \\
\text { Mm'è sempe piaciuto } \\
\text { di stare in allegria. } \\
\text { Io, la malinconia, } \\
\text { nun saccio che cos'è! }\end{array}$ & $\begin{array}{l}\text { Since I was born I have } \\
\text { A very bad defect } \\
\text { That I never got rid of, } \\
\text { I wonder why! } \\
\text { I always liked } \\
\text { To enjoy myself. } \\
\text { What melancholy is, } \\
\text { I really don't know! }\end{array}$ \\
\hline $\begin{array}{l}\text { Sarrà difetto gruosso chistu ccà! } \\
\text { (ride) Ah, ah, ah, ah. } \\
\text { Ma 'o tengo e nun mm' 'o pozzo cchiù } \\
\text { levà! } \\
\text { (ride) Ah, ah, ah, ah. }\end{array}$ & $\begin{array}{l}\text { It's probably a big weakness, this one } \\
\text { here! } \\
\text { (laughs) Ha, ha, ha, ha! } \\
\text { But I have it and I can't get rid of it! } \\
\text { (laughs) Ha, ha, ha, ha. }\end{array}$ \\
\hline $\begin{array}{l}\text { Io rido si uno chiagne, } \\
\text { si stongo disperato, } \\
\text { si nun aggio magnato, } \\
\text { rido senza penzà. } \\
\text { Chist'è 'o difetto mio, } \\
\text { vuje già mo lu ssapite, } \\
\text { 'nzieme cu me redite } \\
\text { ca bene ve farrá! }\end{array}$ & $\begin{array}{l}\text { I laugh when someone cries, } \\
\text { when I'm desperate, } \\
\text { when I'm hungry, } \\
\text { I automatically laugh. } \\
\text { This is my flaw, } \\
\text { You know it already, } \\
\text { Laugh with me } \\
\text { It will be good for you! }\end{array}$ \\
\hline $\begin{array}{l}\text { Redite e ghiammo jà: } \\
\text { (ride) ah, ah, ah, ah! } \\
\text { Ca bene ve farrà: } \\
\text { (ride) ah, ah, ah, ah. }\end{array}$ & $\begin{array}{l}\text { Laugh and let's go: } \\
\text { (laughs) Ha, ha, ha, ha! } \\
\text { It will be good for you, } \\
\text { (laughs) Ha, ha, ha, ha. }{ }^{47}\end{array}$ \\
\hline
\end{tabular}

Fig. 4: Cantalamessa, "'A risa," lyrics

45 See note 6.

${ }^{46}$ The lyrics are printed in the sheet music for "A risa." The song originally comprises three stanzas, but the film uses only two of them in a free arrangement.

47 The English translation is mine. 
Again, Visconti has the guitarist walk around the guests beginning with the groups seated down in the garden. The musician's performance is interspersed with buffoonish behavior as well as slightly obscene gestures, such as an explicit movement of the hip towards a woman at the Russian table. In the middle of the song, then, the actual singing ceases for a moment as waves of giggling break out in the audience. The guitarist alone then revisits Aschenbach on the terrace, continuing incessantly with his rhythmical laughter. As the singer approaches Tadzio (who is not visible in the frame), Aschenbach tosses and turns uneasily in his chair. After a prolonged zoom shot lingering on his erect posture and anxious face, Visconti cuts to the whole ensemble, who have meanwhile returned to the original position (figure 5). Compared to the novella, the performance resumes in a less hysterical manner. The mean-spirited guitarist brazenly points his finger at the hotel guests, taunting them with derisive laughter as the song continues. The camera remains focused on the band vanishing into the dark from where it had come. In a last close-up, the guitarist's starkly lit pale face reemerges from the darkness, sticking his tongue out.

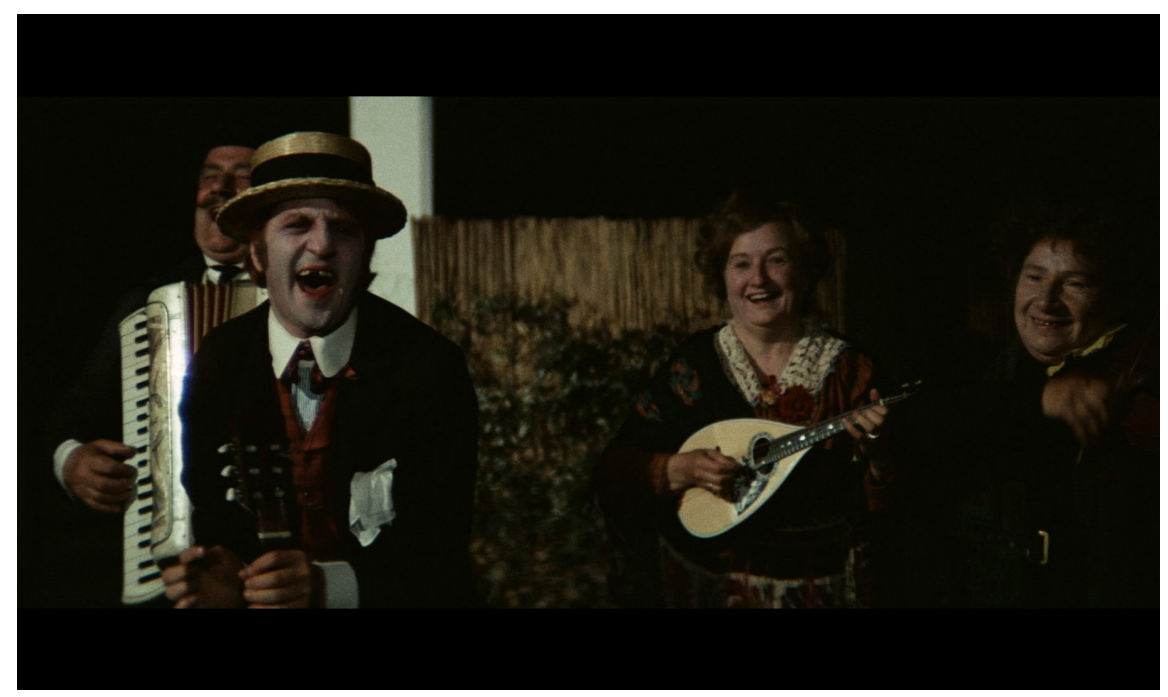

Fig. 5 Visconti, Death in Venice, mocking of the audience 


\section{Uncanny Resemblances: Death in Venice and Doctor Faustus}

In the film, the mysterious figures not only share similar features, such as a foreign look and obnoxious behavior, but they all laugh at Aschenbach in a devilish manner. This is not the case in the novella, and it seems unlikely that Visconti simply added this element to make their relationship more obvious. The entrance of the young-old man is a case in point: before he enters the frame, we hear a goat-like bleating sound turning into sardonic laughter when the camera catches his sight with a quick zoom-in. The gondolier, too, answers the protagonist's feeble objection to being taken to the Lido by him with a sneering laugh before continuing with his unintelligible murmuring.

This chain of motivic association, however, also comes to include the protagonist himself as well as Alfred, his friend (or alter ego). After Aschenbach's breakdown at the fountain, Visconti cuts to a symphonic performance of one of his works, which is booed by the audience. The scene does not represent an actual flashback, but rather a nightmare, as is clarified afterwards when we see Aschenbach tossing and screaming in his hotel bed. In the dream, he begs Alfred to send the hostile audience away: "Send them away? I will deliver you to them!" shouts the latter, breaking out in vicious laughter. Since his friend's philosophical outpourings on music's ambiguity and the demonic side of artistic creation directly reveal Doctor Faustus as their source of origin, his laughter, too, gains an uncanny diabolical resonance.

To be sure, Visconti's conflation of the two Mannian subjects has not gone without criticism. However, while his interpretative approach is certainly idiosyncratic, there are striking thematic similarities that should be considered. Aschenbach and Leverkühn are both driven by a subconscious desire for inspiration and transgression, an altered state of consciousness, which they eventually achieve through Dionysian or diabolical intoxication. Tadzio and Esmeralda, whom Visconti parallels by visual and musical means (they both play Beethoven's Für Elise on the piano), serve as catalysts for this experience. Furthermore, in both novels, the Dionysian/diabolical appears in different disguises, as noted by T. J. Reed: "Fate in Doktor Faustus and the technique used to suggest it recall Der Tod in Venedig, often down to minute detail." And he goes on to explain that:

Schleppfuß, who disappears from the university scene with the same suggestive unobtrusiveness as the stranger in the monumental mason's yard, recurs 
like him in the Leipzig guide and in the Devil in Palestrina. The figures of the two works even share the distinctive reddish hair. ${ }^{48}$

In light of these analogies, Visconti's intertextual reworking seems well motivated, even if the palimpsestic overlayering of Aschenbach, Leverkühn, and Mahler bears certain inconsistencies. ${ }^{49}$ When Aschenbach, while leaning wearily against the fountain, eventually erupts in convulsive laughter himself, this gesture not only brings to mind the young-old man, whose decadent appearance he has come to resemble, but it more generally reveals him as a "prefiguration of Leverkühn." ${ }^{\circ}$ Visconti indeed lends particular weight to this moment through the musical synchronization of the scene. Not coincidentally, Aschenbach's outbreak of laughter coincides precisely with the last poignant eruption and subsequent tonal resolution at mm. 94-95 of Mahler's Adagietto. Echoing the music's release of tension, the laughter does not sound desperate but rather liberating, as if the protagonist were finally embracing the demonic inside of him. In the novella, this act of identification (i.e., Aschenbach's final surrendering to Dionysus) occurs during the nightmare: "But the dreamer was now with them, within them: he belonged to the strangergod. ... And his soul savored the debauchery and delirium of doom." ${ }^{51}$ Though Visconti's scene does not quite match the symbolic explicitness of this depiction, it nevertheless hints at Aschenbach's yielding to the darker forces he has tried to suppress. The mocking laughter, culminating in the laughing song of the guitarist, now has become his own.

\section{Transforming the performance}

As a musical moment of liminality and transformation, the performance of the street musicians in Mann's novella calls for adaptation. Not only does it lend itself to theatrical, operatic, and even cinematic treatment-if we think of the exchange of looks between Aschenbach and Tadzio-but it also evokes a strong sense of corporeality which gains a new kind of perform-

${ }_{48}$ T.J. Reed, Thomas Mann: The Uses of Tradition (Oxford: Clarendon Press, 1974), 395, $395 n 79$.

${ }_{49}$ Most obviously, Mahler's music hardly embodies the rigorous formalism and lack of sensual quality that Alfred accuses Aschenbach of.

${ }^{50}$ Vaget, "Film and Literature," 172.

${ }^{51}$ Mann, Death in Venice, 128-29. 
ative presence, whether on stage or the screen. At the heart of the scene lies the idea of contagious laughter as a comical device that is infused with tragic forebodings. The guitarist-singer himself is an ambiguous figure oscillating between the demonic and the Dionysian, between devil and buffo. As such, his laughter is ambiguous, too, turning from comedy to mockery as it takes over the audience, eliciting an altered state of consciousness.

In Britten's opera, the scenario is turned inside out as a staged projection of fears residing within the protagonist who seems to castigate his own desires. The songs performed by the Strolling Players hint with more or less subtle allusions at his hopeless condition. The Leader, though musically connected to the Dionysian principle, also performs the role of a mesmerist dominating the will of the members of the audience by turning them into accomplices of his act of humiliation through laughter. Thereby, the transformative space of the performance is radically altered. The scene's importance rests on the fact that it carves out a space for the inner voice of conscience, closely echoing the morally charged rhetoric and ironic distancing supplied by the narrator of the novella, once Aschenbach begins drifting into the "dangerous" quicksand of erotic obsession. Following his declaration of love as climax of act 1 -which, as Christopher Chowrimootoo notes, exhibits stronger visceral charms than critics have generally admitted ${ }^{52}-$ Aschenbach himself occasionally pauses with moments of self-accusation. The performance of the Strolling Players, however, provides a more substantial counterbalance in this regard. This is apparent in its gradual shifting from the lighter, ironic humor of the duet "O mio carino" to the darker, menacing tone of the Leader's solo numbers.

Visconti's adaptation initially focuses on the gaze motif that characterizes the disembodied relationship between Aschenbach and Tadzio. In the second part of the scene, however, the music becomes the dominant force as the devilish guitarist walks around the audience and performs his act of mimetic contagion. Here, too, we witness a dissolution of boundaries, when he starts pointing his mocking finger first at Aschenbach and finally at all of the noble guests in their blatant ignorance. While Visconti takes more liberty with the novella as a whole, his treatment of the scene stays quite close to the original setting. By inserting popular Italian songs from

${ }^{2}$ Though I would not necessarily reduce the climaxing gesture of the orchestra to a sounding "evocation of orgasm," I sympathize with Chowrimootoo's defense of the sensually appealing qualities of Britten's musical rhetoric. See "Bourgeois Opera: Death in Venice and the Aesthetics of Sublimation," 204-7. 
the time, including Cantalamessa's " 'A risa," the acoustic space of the novella is invoked in a way that rings with authenticity. This sense of recovering a bygone time through a plenitude of historical detail in terms of setting, costume, and music, is an underlying tenet of Visconti's period films, allowing the spectator to "savor the sights and sounds of the past." ${ }^{33}$ With the use of Cantalamessa's laughing song in particular, the film reaches back behind the source-text, thus uncovering a further layer of the novella's own intertextually as well as intermedially resonant character.

${ }^{53}$ Giorgio Biancorosso, "Ludwig's Wagner and Visconti's Ludwig," in Wagner and Cinema, ed. Jeongwon Joe and Sander L. Gilman (Bloomington: Indiana University Press, 2010), 336. 


\section{Works Cited}

Scores

Britten, Benjamin. Death in Venice. An opera in two acts, op. 88. Libretto by Myfanwy Piper, based on the short story by Thomas Mann. Piano reduction by Colin Matthews. Vocal score (o-571-50514-7). London: Faber Music Ltd, 1974.

Death in Venice. An opera in two acts, op. 88. Libretto by Myfanwy Piper, based on the short story by Thomas Mann. Full score (o-571-53939-4). London: Faber Music Ltd, 1979.

\section{Literature}

Banks, Paul, ed., Benjamin Britten: A Catalogue of the Published Works. Aldeburgh: Britten-Pears Library, 1999.

Biancorosso, Giorgio. "Ludwig's Wagner and Visconti's Ludwig." In Wagner and Cinema, edited by Jeongwon Joe and Sander L. Gilman, 333-57. Bloomington: Indiana University Press, 2010.

Brooks, Tim. Lost Sounds: Blacks and the Birth of the Recording Industry, 1890-1919. Urbana: University of Illinois Press, 2006.

Chowrimootoo, Christopher. "Bourgeois Opera: Death in Venice and the Aesthetics of Sublimation." Cambridge Opera Journal 22, no. 2 (2010): 175-216.

Cooke, Mervyn. Britten and the Far East: Asian Influences in the Music of Benjamin Britten. Woodbridge: The Boydell Press, 1998.

Cutchins, Dennis. "Bakhtin, Intertextuality, and Adaptation." In The Oxford Handbook of Adaptation Studies, edited by Thomas Leitch, 71-86. New York: Oxford University Press, 2017.

Dierks, Manfred. Studien zu Mythos und Psychologie bei Thomas Mann. An seinem
Nachlaß orientierte Untersuchungen zum «Tod in Venedig», zum "Zauberberg» und zur «Joseph»-Tetralogie. Bern: Francke, 1972.

Evans, Peter. The Music of Benjamin Britten. Oxford: Clarendon Press, 1996.

Faulstich, Werner and Ingeborg Faulstich. Modelle der Filmanalyse. Munich: W. Fink, 1977.

Fischer-Lichte, Erika. The Transformative Power of Performance: A New Aesthetics. Translated by Saskya Iris Jain. London: Routledge, 2008.

Frasca, Simona. Italian Birds of Passage: The Diaspora of Neapolitan Musicians in New York. New York: Palgrave Macmillan, 2014.

Giannini, Giovanni. Canti popolari toscani, scelti e annotati da Giovanni Giannini. Florence: Barbera, 1902.

Hess-Lüttich, Ernest W.B. and Susan A. Liddell. "Medien-Variationen: Aschenbach und Tadzio in Thomas Manns Der Tod in Venedig, Luchino Viscontis Morte a Venezia, Benjamin Brittens Death in Venice." In Code-Wechsel: Texte im Medienvergleich, edited by Ernest W.B. Hess-Lüttich and Roland Posner, 27-54. Opladen: Westdeutscher Verlag, 1990.

Hillman, Roger. "Deaths in Venice." Journal of European Studies 22, no. 4 (1992): 291-311.

Hindley, Clifford. "Contemplation and Reality: A Study in Britten's Death in Venice." Music \& Letters 71, no. 4 (1990): 511-23.

Hutcheon, Linda. A Theory of Adaptation. 2nd ed. with Siobhan O'Flynn. London: Routledge, 2013.

Isotta, Paolo. Il ventriloquo di Dio: Thomas Mann, la musica nellopera letteraria. Milan: Rizzoli, 1983. 
Kitcher, Philip. Deaths in Venice: The Cases of Gustav von Aschenbach. New York: Columbia University Press, 2013.

Maldacea, Nicola. Memorie di Maldacea: vita, morte e resurrezione di un Lazzaro del XX secolo. Naples: F. Bideri, 1933.

Mann, Thomas. Death in Venice. Translated by Michael Henry Heim. New York: HarperCollins, 2004.

- Mario and the Magician and Other Stories. Translated by Helen Tracy LowePorter. London: Vintage, 1996.

Matthews, Colin. "The Venice Sketchbook." In Mitchell, Benjamin Britten: "Death in Venice," 55-66.

Mitchell, Donald, ed. Benjamin Britten: "Death in Venice." Cambridge: Cambridge University Press, 1987.

Palmer, Christopher. "Britten's Venice orchestra." In Mitchell, Benjamin Britten. "Death in Venice," 129-53.

Petrella, Fausto. L'ascolto e l'ostacolo: psicoanalisi e musica. Milan: Jaca Book, 2018.

Pesce, Anita. La sirena nel solco: origini della riproduzione sonora. Naples: Guida, 2005.

-. "The Neapolitan Sound Goes Around: Mechanical Music Instruments, Talking Machines, and Neapolitan Song, 1850-1925." In Neapolitan Postcards: The Canzone Napoletana as Transnational Subject, edited by Goffredo Plastino and Joseph Sciorra, 45-72. Lanham: Rowman \& Littlefield, 2016.

Piper, Myfanwy. "The Libretto." In Mitchell, Benjamin Britten: "Death in Venice," 45-54.

Reed, Philip. "Aschenbach Becomes Mahler: Thomas Mann as Film." In Mitchell, Benjamin Britten: "Death in Venice," 178-83.

Reed, T.J. Thomas Mann: The Uses of Tradition. Oxford: Clarendon Press, 1974.
Rupprecht, Philip. Britten's Musical Language. Cambridge: Cambridge University Press, 2001.

Said, Edward W. "Not All the Way to the Tigers: Britten's Death in Venice." In On Mahler and Britten: Essays in Honour of Donald Mitchell on His Seventieth Birthday, edited by Philip Reed, 267-74. Woodbridge: The Boydell Press, 1995.

Sessa, Andrea. Il melodramma italiano, 1861-19oo: dizionario bio-bibliografico dei compositori. Florence: Olschki, 2003.

Sheppard, W. Anthony. Revealing Masks: Exotic Influences and Ritualized Performance in Modernist Music Theater. Berkeley: University of California Press, 2001.

Singer, Irving. "Death in Venice: Visconti and Mann." MLN 91, no. 6 (1976): 1348-59.

Smith, Jacob. Vocal Tracks: Performance and Sound Media. Berkeley: University of California Press, 2008.

Stam, Robert. "Beyond Fidelity: The Dialogics of Adaptation." In Film Adaptation, edited by James Naremore, 54-76. New Brunswick: Rutgers, 2000.

Tigri, Giuseppe. Canti popolari toscani: raccolti e annotati da Giuseppe Tigri. Florence: Barbera, 1856.

Tommaseo, Niccolò. Canti popolari toscani, corsi, illirici, greci, raccolti e illustrati da $N$. Tommaseo con opuscolo originale del medesimo autore. 4 vols. Venice: Girolamo Tasso, 1841.

Vaget, Hans Rudolf. "Film and Literature. The Case of Death in Venice: Luchino Visconti and Thomas Mann." The German Quarterly 53, no. 2 (1980): 159-75.

Weiner, Marc A. "Silence, Sound, and Song in Der Tod in Venedig: A Study in Psycho-Social Repression." Seminar: A Journal of Germanic Studies 23, no. 2 (1987): 137-55. 
Whitesell, Lloyd. "Notes of Unbelonging." In Benjamin Britten Studies: Essays on An Inexplicit Art, edited by Vicki P. Stroeher and Justin Vickers, 214-34. Woodbridge: The Boydell Press, 2017.

Wiehe, Roger. "Of Art and Death: Film and Fiction Versions of Death in Venice." Literature/Film Quarterly 16, no. 3 (1988): 210-15.

"The Danse macabre as the Crucial Moment in Story and Film Versions of Death in Venice." In The Symbolism of Vanitas in the Arts, Literature, and Music: Comparative and
Historical Studies, edited by Liana DeGirolami Cheney, 85-99. Lewiston: Mellen, 1992.

Wilson, Michael. "Art is Ambiguous: The Zoom in Death in Venice." Literature/Film Quarterly 26, no. 2 (1998): 153-56.

Zoppelli, Luca. "'Stage Music' in Early Nineteenth-Century Italian Opera." Cambridge Opera Journal 2, no. 1 (1990): 29-39.

\section{Abstract}

This paper takes as its starting point a scene from the fifth chapter of Thomas Mann's novella Death in Venice (1912). While Venice is threatened by an outbreak of cholera, a group of Neapolitan street musicians plays in front of Aschenbach, Tadzio, and the other hotel guests. The leader of the band-a buffonesque guitarist-singer with red hair and a wrinkled, emaciated face-is an ominous figure whose facetious, sexually charged performance eventually turns into blatant mockery of the audience, whom he infects with his contagious laughter. Using the concept of "performance as transformation" (Erika Fischer-Lichte) as a lens through which to investigate the filmic and operatic adaptations of the scene in Luchino Visconti's Death in Venice (1970) and Benjamin Britten's eponymous opera (1973), I focus on the various renditions of the laughing song to trace the particular transformative power it unfolds across media. Both adaptations use music to ironically comment on Aschenbach's infatuation. Yet, their approach to the scene at large is distinct from one another: While the opera turns the performance into an interiorized space of moral interrogation, the film evokes the sound of the past through the insertion of pre-existent popular songs from the time, including Berardo Cantalamessa's Neapolitan laughing song "A risa." As I argue, the latter served as a model for the uproarious comical number described by Mann which thus constitutes a "phono-graphic" adaptation itself. Finally, I discuss the recurrences of demonic laughter throughout the film as part of Visconti's intertextual strategy to create motivic relationships between Death in Venice and Doctor Faustus (1947).

Janina Müller studied musicology, art history, and cultural history and theory at the Humboldt University of Berlin. There she completed her doctorate in 2018 with a thesis on film noir music (published as Musik im klassischen Film noir, Würzburg 2019). Her research interests include nineteenth- and twentieth-century music, music in audiovisual media and radio, music theater, and the history of music listening. From 2013 to 2018 she held teaching and research positions at the Humboldt University of Berlin, the University of Leipzig, and the Berlin University of the Arts. She currently works as a postdoctoral researcher at the KU Leuven in Belgium. Her project on radiophonic composing in the context of 1968 is funded by a junior postdoctoral fellowship from the FWO (Research Foundation - Flanders; 2020-2023). 